\title{
STUDY OF THE WATER QUALITY IN THE SHATT AL-ARAB RIVER SOUTHERN OF IRAQ: A REVIEW
}

\section{Zahraa Qadra Lateef}

Graduate Student, Department of Environmental Engineering, College of Engineering, Mustansiriyah University,Baghdad , Iraq

\begin{abstract}
The Shatt Al-Arab River located at southern of Iraq is ranging $8,000-30,000 \mathrm{~km}^{2}$ in size. Freshwater delivery to such system has been influenced through the water control structures being constructed within neighboring countries and Iraq. Normally, lower than $10 \%$ of such marshes were of function. The current review try to summarize the available information on quality of water of such unique and vast ecosystem. These data come from numerous scientific articles. Quality of water variables under consideration including ionic composition, salinity, and various variables inrespect to nutrients status. Such information illustrate that salinity has elevated by time, negatively influencing agriculture in the southe. Generally, concentrations of dissolved $\mathrm{O}_{2}$ are high, waters are normally slightly alkaline, and aquatic submerged vegetation extensively assistes suspended solids settling. $\mathrm{NO}_{3}$ are the major inorganic $\mathrm{N}$ where concentrations being low in compareson to other bodies of water. Experiments in limitation of nutrients mentioned that the phytoplankton were $\mathrm{N}$ limited.
\end{abstract}

Keywords: water quality; Iraq; Shatt Al-Arab River; Mesopotamia; marshes; pollution.

\section{Introduction}

Water quality is a major health and disease control factor for both human and animals.
Water quality in an area is affected by natural processes (weathering processes, precipitation rates, and sediment transportation) and anthropogenic inputs (effluents of municipal and industrial wastewater, urban development and farming) [1]. The anthropogenic waste is usually a constant pollutant source. Fluctuation in water quality is considered a seasonal phenomenon which is heavily affected by climate [2]. However, intensive investigations for the anthropogenic contamination of ecosystems are continuously carried out for areas which receive such contaminations [3].

Over the last decades, there was a need for increasing demand to observe the water standard of different rivers by frequent measurements using different water quality parameters[4]. The water quality for the water resources tends to be a topic of ongoing concern. The evaluation of changes in long-term water quality is a further problem that is challenging. Also, the uncontrolled wastewater releases are of perpetual and immediate impact when it comes to the users.

\footnotetext{
*Corresponding Author: zahraa.latif.14@gmail.com
} 
As it is known, the rivers are utilized for various applications, for example, water system, residential and mechanical utilizations and it is the fundamental standard water supply for people. For water resources, regular water quality monitoring is required to evaluate the water quality for environmental hygiene and health along of its use for domestic, industrial use, and agricultural purposes[5].

Reported human activities by Niemi et al. (1990) [6] showed that a major determinant of water and groundwater quality is effluent discharges, use of agricultural chemicals, atmospheric pollution, soil erosion, and land use. Water pollution sources are now the main feature of public concern. Some countries, such as the under-developed countries, have been inflicted by pollution impacts that are attributed to the disordered economic growth relating to the natural resource exploitation.

Figure.1shows that Shatt Al-Arab River involve the Mesopotamian Valley southeastern and south pieces $(32.7557 \mathrm{o} N, 48.0128 \mathrm{o} \mathrm{E})$. Territory environment has blistering and short summers, more than winters being chilly; the predominant breezes as north-west impact the region [7]. This part is the most significant unit of topography in southe of Mesopotamia and manifests lacustrine as complex sedimentary situation [8]. Guideline of river flows from Euphrates and Tigris by Syria, Turkey and Iran, are essentially used for farming, however, it had contributed in diminishing these wetlands. Based by IUCN (2005) In Iraq, development of impoundments expanded water system for farming just as the wetlands depleting for agribusiness has likewise influenced the water conveyance timing and amount to such wetlands [9]. Application in compound variables causing anxieties that are numerous general in the quality of water [10]. The monitoring of water quality is needed to provide an overview of water quality and to keep track of trends for long-range of the selected water quality parameters. The water quality monitoring is principally four primary approaches can be applied for water body water quality evaluation, such approaches are index of water quality, index of trophic status, statistical water quality data analysis and biological analysis with other different biological indices [10]. The water quality evaluation might be a difficult application in variable compounds leading to anxieties that are numerous general in the quality of water [11]. The monitoring of water quality is needed to provide an overview of water quality and to keep track of trends for long-range of the selected water quality parameters [12]. The water quality monitoring is used to detect actual or possible problems for water quality and to find specific causes and to determine the effect of any kind of convective activity. Nowadays, computer systems offer the opportunity of handling and manipulating databases in many ways that have not been formerly a practical option. Nevertheless, in recent decades, population growth, runoff of sewage from urban areas, and agricultural practices increase nutrient inputs to the level of their natural occurrence, causing accelerated eutrophication[13].

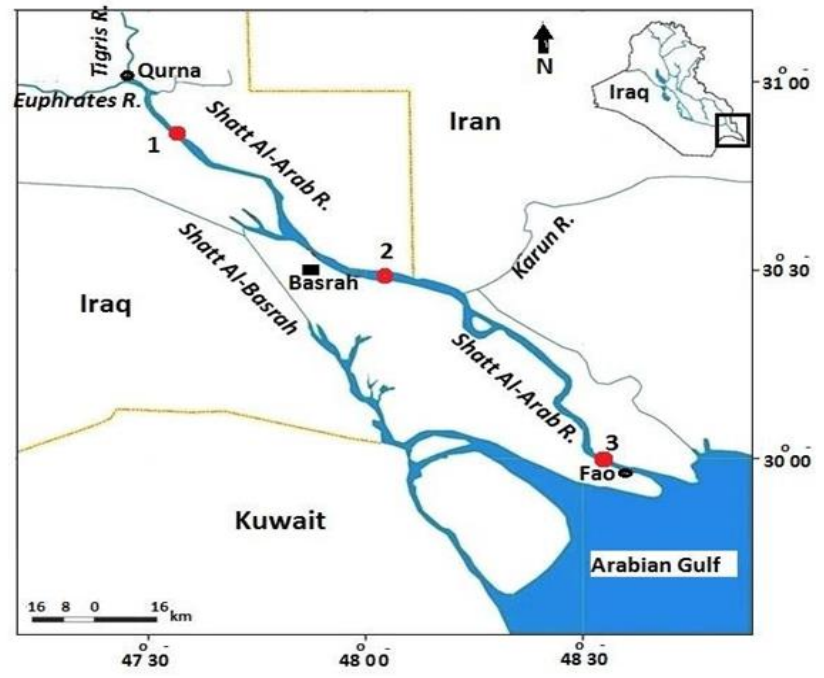

Figure.1. Map of Shatt Al-Arab River [7] 
Shatt Al Arab water branches contains all immense pollution into main river. These branches have numerous origins of contamination of potential effects and water quality breaking down. In focal point of Basrah territory, there are many water treatment plants conveyed on Shatt Al-Arab River right bank which is the reason the wastewater that contains Aluminum, iron and the dangerous chemical is disposed of there. Notwithstanding waste removals leakage from septic tanks and the towns which circulated extremely near the stream course and the horticultural effluents, are the significant wellsprings of pollution. Furthermore, Hartha and Najabia electric force stations release its wastewater into the stream. At last, the contamination of the Shatt Al Arab River is might have alluded to the effluents of different modern squanders approaching at the waterway water. The contamination of the Shatt Al Arab River is likewise because of the expansion of water withdrawals and the wastewater releases, particularly in its branches into the waterway that compromised the seagoing existence of the stream. The review aims to summarize previous studies results on the quality of water in Shatt Al-Arab River southern of Iraq and to highlight factors as water quality key influencing the functions and structure of such ecosystem being unique.

\section{Water Temperature (WT)}

Among other things, temperature is a significant factor in the balance of the aquatic environment, and the change on temperature due to the remnants of industrial heat caused a thermal pollution, the temperature effects on viscosity of water, it is effect on the speed and effectiveness of microbial processes, effective analysis of organic matter will increasing, high temperature is also leads to killing of some species of aquatic organisms and decrease the amount of O2 dissolved water, which effects on the process of self-purification, and leads to emergence of a new types of plants and animals. All of this leads to emergence of nonenvironmental balance. The best temperature for drinking water is ranging from $\left(9-12 \mathrm{C}^{0}\right)$, the temperature in Iraq's river is ranging from (7-19 $\left.\mathrm{C}^{0}\right)$ in winter and from $\left(23-30 \mathrm{C}^{0}\right)$ in summer [14]. The studies that reported the WT in Shatt Al-Arab River are illustrated in Table 1.

\section{Total Dissolved Solids (TDS), Salinity (Sal.) \& (EC)}

The gathering of each separated constituent in water is assessed "Salinity" is consistently used comparably with "complete broke down solids" regardless of the way that that expect that the aggregate of the deteriorated solids is saline. Saltiness is higher than an estimation of the total $\mathrm{Na}$ and $\mathrm{Cl}$ exist in water. Saltiness moreover consolidates anions, for instance, carbonates that have been changed over to oxides, bicarbonate and sulfate bromide and iodine displaced by $\mathrm{Cl}$, and cations, for instance, $\mathrm{Ca}$, $\mathrm{Mg}$, and each and every characteristic issue have been oxidized [15].

The US-EPA excludes recommendations for TDS , anyway WHO (2011) reported that level of TDS not actually around $600 \mathrm{mg} / \mathrm{l}$ is usually seen as incredible , but levels around $1000 \mathrm{mg} / \mathrm{l}$ raises concerns of classiness.Based by APHA (2005), EC has been characterized as a proportion of the capacity of a fluid to mediate an electric flow, contingent upon the nearness particles, on their valence and concentration, portability, and on the temperature of measurement [16]. Generally, bases, salts and acids being inorganic compounds are conductors being acceptable, whereas salts and acids as organic mixtures are poor conductors moderately as a result of their most minimal water ionization [17]. The studies that reported the TDS, Sal. and EC in Shatt Al-Arab River Southern of Iraq are tabulated in Table 1. 
Table 1. Summary of the studies reported the mean value of WT, TDS, Sal. and EC

\begin{tabular}{|c|c|c|c|c|c|c|}
\hline Study area (All selected locations in Basra city) & Period of Study & WT $\left(\mathbf{C}^{\mathbf{0}}\right)$ & TDS (mg/l) & Sal. $(\%)$ & $\mathrm{EC}(\mathrm{mS} / \mathrm{cm})$ & Ref. \\
\hline Najibia power plant & $\begin{array}{c}2002,2003,2004,2005,2006,2007,2008, \\
2009,2010,2011 \text { and } 2012\end{array}$ & $\begin{array}{c}27,23,28,20,29 \\
45.6,23,24,24.5,24.2 \\
\text { and } 23.7 \\
\end{array}$ & - & - & - & {$[18]$} \\
\hline $\begin{array}{l}\text { Al-Qurna, Paper factory, Al-Sindebad, Al-Ashar, } \\
\text { Al-Sebah and Al-Fao }\end{array}$ & Aug/2008-Jul/2009 & 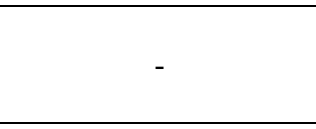 & $\begin{array}{c}1679,1848 \\
1586,1662 \\
1945 \text { and } 1800 \\
\end{array}$ & - & $\begin{array}{l}2.12,2.53,2.20,2.53 \\
2.25 \text { and } 2.24\end{array}$ & [19] \\
\hline Sindibad, Ashar, Abu AL-Khaseeb and Fao & Winter 2009 - Summer 2010 & $\begin{array}{c}18.7-33.7 \\
15.9-26 \\
18.2-26.97 \\
20.1-23.4 \\
\end{array}$ & - & $\begin{array}{c}5.8-1.9 \\
7.3-1.7 \\
6.8-2.2 \\
12.4-3.5 \\
\end{array}$ & - & {$[20]$} \\
\hline $\begin{array}{l}\text { Basrah oil refinery } \\
\text { (3 stations) }\end{array}$ & Oct/2009-July/2010 & 26.25 & $\begin{array}{c}4330,3562 \text { and } \\
3887\end{array}$ & - & - & {$[21]$} \\
\hline $\begin{array}{c}\text { Staion-1 } \\
\text { Staion-2 } \\
\text { Staion-3 } \\
\text { Staion-4 } \\
\text { Staion-5 } \\
\text { Staion-6 } \\
\text { Staion-7 } \\
\text { Staion-8 } \\
\text { Staion-9 } \\
\text { Staion-10 } \\
\end{array}$ & Oct/2009-Sep/2010 & $\begin{array}{l}15.1-29.6 \\
15.2-29.6 \\
15.4-30.6 \\
16.8-33.7 \\
17.3-33.9 \\
16.4-33.9 \\
16.6-35.2 \\
17.5-34.4 \\
17.5-33.9 \\
16.7-33.4 \\
\end{array}$ & $\begin{array}{c}789-1956 \\
586-3120 \\
835-2508 \\
1446-9982 \\
1465-9774 \\
1497-6069 \\
1632-14811 \\
1145-20615 \\
870-35524 \\
3190-42409 \\
\end{array}$ & $\begin{array}{c}0.6-1.1 \\
0.7-2.6 \\
1.1-2.0 \\
1.5-8.1 \\
1.5-8.6 \\
1.6-6.3 \\
1.7-12.5 \\
1.0-16.7 \\
0.8-29.9 \\
3.2-40.4 \\
\end{array}$ & $\begin{array}{c}1.35-1.72 \\
1.45-4.89 \\
1.73-3.84 \\
2.38-13.93 \\
2.29-14.80 \\
2.7-11.21 \\
3.18-20.80 \\
1.50-27.20 \\
1.36-46.10 \\
5.6-60.20 \\
\end{array}$ & {$[22]$} \\
\hline Shatt Al Arab River in Basrah city & Monthly from 2010 to 2012 & - & 1060.0 & - & 2.16 & {$[23]$} \\
\hline Garma I, Al-Muwahad, Twenty five and Jubaila & Mar, Apr, May and Octo/ 2011 & - & $\begin{array}{c}1647.2,1521.6 \\
1411.9 \text { and } \\
1348.1 \\
\end{array}$ & - & - & {$[r \varepsilon]$} \\
\hline St-1, St-2, St-3, St- 4 , St-5, St-6, St-7, St- 8 and St- 9 & autumn season, October 2011 & $\begin{array}{l}19,19,20.2,21.10 \\
21.19,22.33,21.8 \\
20.75 \text { and } 21.4\end{array}$ & $\begin{array}{c}2250,2400, \\
1670,6740, \\
2160,3808, \\
4044,3788 \text { and } \\
3139\end{array}$ & - & $\begin{array}{c}1.6,1.99,1.3,5.08 \\
20.82,39.19,41.92 \\
38.19 \text { and } 38.19\end{array}$ & {$[25]$} \\
\hline $\begin{array}{c}\text { Baradia, Shatt Al- Arab , Al- Rabat, Al Jubiala, } \\
\text { Garma 1, Garma 2, Twenty Five Millon, Basrah } \\
\text { Mohad, Al Diar and Al Qurna }\end{array}$ & Mar/2011-Mar/2012 & - & $\begin{array}{c}1946,1821, \\
1648,2331, \\
1435,1770, \\
1061,982.8, \\
1284 \text { and } 990 \\
\end{array}$ & - & $\begin{array}{l}3.502,2.990,2.666 \\
2.289,2.361,2.925 \\
1.889,1.918,2.134 \\
\quad \text { and } 1.830\end{array}$ & {$[26]$} \\
\hline $\begin{array}{c}\text { Qurna, Al- Sindebad, Abu Alkhaseeb, Al-Seba } \\
\text { and Al-Fao }\end{array}$ & Oct/2011-Oct/2012 & $\begin{array}{c}26.95,29.95,22.69, \\
29.07 \text { and } 23.36\end{array}$ & - & - & $\begin{array}{l}2.38,2.35,4.52, \\
14.39 \text { and } 32.56\end{array}$ & {$[27]$} \\
\hline $\begin{array}{c}\text { Garma, Sindbad, Ashar, Mohela, Abuflouse, Seba } \\
\text { and Fao }\end{array}$ & Dec/2012-Nov/2013 & $\begin{array}{c}24.02,23.93,23.28 \\
23.01,22.7,23.53 \text { and } \\
23.81 \\
\end{array}$ & - & - & $\begin{array}{c}2.44,3.88,4.92,5.39 \\
5.15,7.44 \text { and } 24.15\end{array}$ & {$[28]$} \\
\hline Abo Al-Kaseeb, Al-Dear and Qurna & Dec/2012-Nov/2013 & - & $\begin{array}{l}2326,1946 \text { and } \\
1950\end{array}$ & - & $3.95,2.81$ and 2.51 & [29] \\
\hline Qurna, Basrah, Maqual, & Jan/2013-Apr/2013 & - & 1288,1667, & - & $1.93,2.47,5.83,6.25$ & {$[30]$} \\
\hline
\end{tabular}




\begin{tabular}{|c|c|c|c|c|c|c|}
\hline Abo Al-Khasib, Sayba and Al-Fao & & & $\begin{array}{c}4352,4448 \\
2844 \text { and } 9603\end{array}$ & & 4.10 and 14.08 & \\
\hline $\begin{array}{c}\text { Five sampling locations within the Shatt Al Arab } \\
\text { River }\end{array}$ & winter 2014 - summer 2014 & - & $2592-10780$ & - & $3.68-14.67$ & {$[31]$} \\
\hline $\begin{array}{c}\text { ALQurna, Paper factory, Al- Sindebad, Al- Ashare, } \\
\text { AL-Sebah and Al- Fao }\end{array}$ & 2015 & $\begin{array}{l}26.5,27.3,30.4,28.5 \\
29.1 \text { and } 29.4\end{array}$ & $\begin{array}{c}1200,1290, \\
2900,2620, \\
5740 \text { and } 3710\end{array}$ & - & $\begin{array}{l}1.88,2.03,3.14,4.1 \\
8.94 \text { and } 55.6\end{array}$ & {$[32]$} \\
\hline $\begin{array}{c}\text { The region between the confluence of Tigris and } \\
\text { Euphrates Rivers }\end{array}$ & Dec/2016 & - & $1907, \mathrm{rV}$ & - & $r, v r$ & {$[33]$} \\
\hline St-1, St-2, St-3, St-4, St-5 and St-6 & $\begin{array}{l}\text { during the dry season (August, 2016) and } \\
\text { the wet season (January, 2017). }\end{array}$ & $\begin{array}{c}42 \pm 3.7,32 \pm 3.2,31 \\
\pm 3.3,39 \pm 3.9,32 \pm \\
3.2 \text { and } 38 \pm 3.3\end{array}$ & $\begin{array}{c}2065 \pm 51.4 \\
1480 \pm 53.7 \\
1980 \pm 52.6 \\
2752 \pm 54.6 \\
2377 \pm 55.3 \text { and } \\
2441 \pm 53.9\end{array}$ & - & $\begin{array}{c}3.45 \pm 0.85,2.34 \pm \\
0.84,3.09 \pm 0.87 \\
3.78 \pm 0.83,3.75 \pm \\
0.86 \text { and } 3.88 \pm 0.85\end{array}$ & [34] \\
\hline Shatt Al-Arab River in Basrah & $2016-2017$ & 25.4 & roor,o & - & $\varepsilon, \cdot \wedge$ & [35] \\
\hline The Canal of Shatt Al-Basrah & 2017 & - & $177 \mathrm{~V}$ & - & r, ro & {$[36]$} \\
\hline $\begin{array}{c}\text { Hartha, Garma, Ashar } \\
\text {, Abu-Flus, Sihan, Mukhraq, Fao and Ras El-Bisha }\end{array}$ & during the year 2018 & - & - & $\begin{array}{c}10.49,13.81 \\
16.84,20.86 \\
29.18,37.48, \\
39.7 \text { and } 41.85 \\
\end{array}$ & - & [37] \\
\hline
\end{tabular}

\section{Total Hardness (TH), Calcium $\left(\mathrm{Ca}^{+2}\right)$ and Magnesium $\left(\mathrm{Mg}^{+2}\right)$ ions}

Water that contains salts of $\mathrm{Ca}$ and $\mathrm{Mg}$ and, to lesser extent, other polyvalent metals, such as iron, aluminum, and manganese, and that requires large amounts of soap to lather, or that does no evaporate, forms a deposit on the container is referred to as hard water [38].

Hard water doesn't seem to deleteriously affect creatures, yet it frequently is accounted for as a feature of water quality inspection. Water with the highest of TDS or saltiness could conceivably be hard water. Water is arranged by $\mathrm{Ca}$ and $\mathrm{Mg}$ salt substance as follow: delicate water rang 0-60 ppm, moderate water ranges 61-120 ppm, hard water differs 121-180 ppm and hard water is $>181 \mathrm{ppm}[39,38]$.
There are two types of hardness: Carbonate hardness ore temporary hardness which is equal to or less than the sum of the carbonate and bicarbonate alkalinities and precipitates at boiling temperature, and non-carbonate hardness or permanent hardness that exceeds the total alkalinities and does not precipitate at boiling temperature such as sulfate , $\mathrm{Cl}$, and nitrate hardness $[17,38]$.

Ca can be leached from practically all rocks but is much more prevalent in water from region with deposits of limestone, dolomite, and gypsum. Concentrations in water from limestone areas range from $30-100 \mathrm{mg} / \mathrm{l}$. Ca is import to the biological productivity of water, it is considered as a micronutrient for most algae. 
Waters with concentration of $10 \mathrm{mg}$ or less per liter are usually oligotrophic, while waters with $25 \mathrm{mg}$ or more per liter are usually distinctly eutrophic [38].

The most essential component in Chlorophyll and red blood cells are $\mathrm{Mg}$ in common waters that originates from carbonate rocks. A few salts of $\mathrm{Mg}$ are harmful by ingestion or inward breath. Fluid concentrations which are more than $125 \mathrm{mg} / \mathrm{l}$ likewise can have a cleansing and diuretic impact [16]. $\mathrm{Mg}$ is frequently connected with $\mathrm{Ca}$ in a wide range of waters [40].

The studies that reported the $\mathrm{TH}, \mathrm{Ca}^{+2}$ and $\mathrm{Mg}^{+2}$ in the River Southern of Iraq are tabulated in Table 2.

\section{Turbidity (Turb.) and Total Suspended Solids (TSS)}

Turbidity is the dispersion of light measurement in the water column due to colloidal and suspended matters. The highest the turbidity, the cloudiest the water appears. Too turbid water can't lose the ability to provide a majority of plants [41]. Virtually all effluents contain suspended solid matter TSS, but especially, stone and other mineral materials, engineering works, dredging and boat traffic commonly introduce particulate matter into suspension [42].

Furthermore, the runoff of surface water contributes to substantial loads. The blanketing effect and increased turbidity of the particulates constitutes an indirect effect if they settle eventually. Turbidity increase prevents or declines photosynthesis, leading to a decline in primary plants productivity or complete elimination [43]. The studies that reported the Turb. and TSS in the River are shown in Table 3.

\section{Sulfate $\left(\mathrm{SO4}^{-2}\right)$ ions}

Sulfate is found in most of the natural water as compounded with cations at few milligrams concentrations to thousands of $\mathrm{mg} / \mathrm{L}$ [17]. Sulfate considered as one of the least anions being toxic where WHO not recommend any value as guideline for it in drinking water. Nevertheless, dehydration, gastrointestinal and catharsis irritation have been noticed in drinking water at high concentrations and WHO thus proposes that authorities of health should be informed if concentrations exceed $500 \mathrm{mg} / \mathrm{l}$ at drinking water [44].

Sulfate is one of the anions that caused dominant hardness in water; also it causes bitter taste if it exceeds $200 \mathrm{mg} / \mathrm{l}$ [17]. Transient diarrhea is a result of elevated sulfates exposure in drinking water. Usually, animals acclimate to sulfate drinking water for 3-7 days where no longer exhibit diarrhea. Methemoglobin elevated by $50 \%$ in cattle drinking water with sulfates of $3493 \mathrm{mg} / \mathrm{l}$ [39].

The studies that reported the $\mathrm{SO}^{-2}$ in River Southern of Iraq are tabulated in Table 4. 
Table 2. Summary of the studies that reported the $\mathrm{TH}, \mathrm{Ca}^{+2}$ and $\mathrm{Mg}^{+2}$ in the Shatt Al-Arab River Southern of Iraq

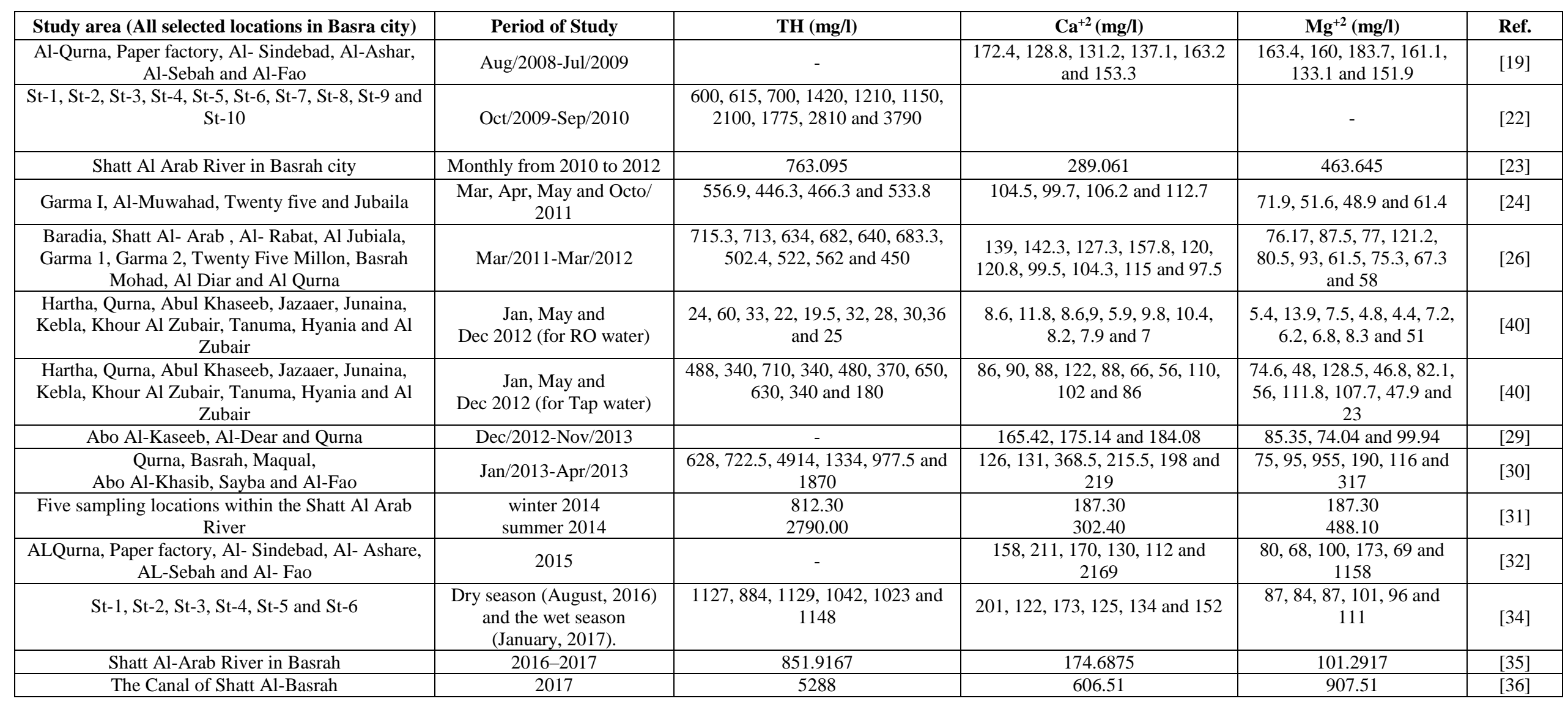


Table 3. Summary of the studies that reported the Turbidity and TSS in the Shatt Al-Arab River Southern of Iraq

\begin{tabular}{|c|c|c|c|c|}
\hline Study area (All selected locations in Basra city) & Period of Study & Turb.(NTU) & TSS (mg/l) & Ref. \\
\hline Najibia power plant & $\begin{array}{l}2002,2003,2004 \\
2005,2006,2007 \\
2008,2009,2010 \\
2011 \text { and } 2012 \\
\end{array}$ & - & $\begin{array}{l}23,27,36.5,30,28 \\
27,45,42.6,42.7,39.6 \\
\quad \text { and } 34.6\end{array}$ & {$[18]$} \\
\hline Basrah oil refinery (3 stations) & Oct/2009-July/2010 & 23 & 31,30 and 20.5 & [21] \\
\hline $\begin{array}{l}\text { St-1, St-2, St-3, St-4, St-5, St-6, St-7, St- } 8, \text { St- } 9 \text { and } \\
\text { St-10 }\end{array}$ & Oct/2009-Sep/2010 & $\begin{array}{c}36.4,17.6, \\
14.3,17.15, \\
23.9,15,16.9 \\
13.95,34.4 \\
\text { and } 73.95 \\
\end{array}$ & $\begin{array}{l}13,18,16,52,51,32 \\
77,103,18 \text { and } 22\end{array}$ & {$[22]$} \\
\hline Garma I, Al-Muwahad, Twenty five and Jubaila & $\begin{array}{l}\text { Mar, Apr, May and } \\
\text { Octo/ } 2011\end{array}$ & - & $16,15,14$ and 13 & [24] \\
\hline $\begin{array}{c}\text { Baradia, Shatt Al- Arab , Al- Rabat, Al Jubiala, Garma } \\
\text { 1, Garma 2, Twenty Five Millon, Basrah Mohad, Al } \\
\text { Diar and Al Qurna }\end{array}$ & Mar/2011-Mar/2012 & $\begin{array}{c}15.6,14, \\
17.26,23.20, \\
25.35,34.5, \\
29.8,23.8, \\
24.9 \text { and } 47.1 \\
\end{array}$ & $\begin{array}{l}19,18,16,23,14,17 \\
10,98,12 \text { and } 9\end{array}$ & [26] \\
\hline $\begin{array}{c}\text { Qurna, Basrah, Maqual, } \\
\text { Abo Al-Khasib, Sayba and Al-Fao }\end{array}$ & $\mathrm{Jan} / 2013-\mathrm{Apr} / 2013$ & - & $\begin{array}{l}128,166,43,44,28 \\
\text { and } 96\end{array}$ & [30] \\
\hline $\begin{array}{l}\text { Five sampling locations within the Shatt Al Arab } \\
\text { River }\end{array}$ & $\begin{array}{c}\text { winter } 2014 \\
\text { summer } 2014\end{array}$ & - & $\begin{array}{c}25 \\
107\end{array}$ & [31] \\
\hline $\begin{array}{c}\text { ALQurna, Paper factory, Al- Sindebad, Al- Ashare, } \\
\text { AL-Sebah and Al- Fao }\end{array}$ & 2015 & $\begin{array}{l}25.02,15.40 \\
31.03,9,59.8 \\
\quad \text { and } 120 \\
\end{array}$ & $\begin{array}{c}14,25,30,20,47 \text { and } \\
150\end{array}$ & [32] \\
\hline $\begin{array}{c}\text { The region between the confluence of Tigris and } \\
\text { Euphrates Rivers }\end{array}$ & Dec/2016 & 34.75 & 365.95 & [33] \\
\hline St-1, St-2, St-3, St-4, St-5 and St-6 & $\begin{array}{l}\text { (Aug., 2016) and (Jan., } \\
\text { 2017) }\end{array}$ & - & $\begin{array}{c}20,14,19,27,23 \text { and } \\
24\end{array}$ & [34] \\
\hline Shatt Al-Arab River in Basrah & $2016-2017$ & 7.47 & 100.83 & [35] \\
\hline
\end{tabular}

Table 4. Summary of The studies that reported the $\mathrm{Cl}^{-}, \mathrm{Na}^{+}$and $\mathrm{K}^{+}$in the Shatt Al-Arab River Southern of Iraq

\begin{tabular}{|c|c|c|c|c|c|c|}
\hline $\begin{array}{l}\text { Study area(All selected } \\
\text { locations in Basra city) }\end{array}$ & Period of Study & $\mathrm{SO}_{4}^{-2}(\mathrm{mg} / \mathrm{l})$ & $\mathrm{Cl}^{-}(\mathrm{mg} / \mathrm{l})$ & $\mathrm{Na}^{+}(\mathrm{mg} / \mathrm{l})$ & $\mathbf{K}^{+}(\mathbf{m g} / \mathbf{l})$ & Ref. \\
\hline Najibia power plant & $\begin{array}{c}2002,2003, \\
2004,2005, \\
2006,2007, \\
2008,2009, \\
2010,2011 \text { and } \\
2012 \\
\end{array}$ & - & $\begin{array}{l}660,680,350, \\
400,360,370 \\
580,700,600, \\
410 \text { and } 483.5\end{array}$ & - & - & {$[18]$} \\
\hline $\begin{array}{c}\text { Basrah oil refinery (3 } \\
\text { stations) }\end{array}$ & $\begin{array}{l}\text { Oct/2009- } \\
\text { July/2010 }\end{array}$ & $\begin{array}{l}1806,1325 \\
\text { and } 1544\end{array}$ & - & - & - & [21] \\
\hline $\begin{array}{l}\text { Garma I, Al-Muwahad, } \\
\text { Twenty five and Jubaila }\end{array}$ & $\begin{array}{l}\text { Mar, Apr, May } \\
\text { and Octo/ } 2011\end{array}$ & $\begin{array}{c}1050.8,925.2 \\
919.2 \text { and } \\
1023.6 \\
\end{array}$ & $\begin{array}{c}\text { 444.9, } 303.7, \\
319.9 \text { and } 382.4\end{array}$ & - & - & [24] \\
\hline $\begin{array}{l}\text { Baradia, Shatt Al- Arab, Al- } \\
\text { Rabat, Al Jubiala, Garma 1, } \\
\text { Garma 2, Twenty Five } \\
\text { Millon, Basrah Mohad, Al } \\
\text { Diar and Al Qurna }\end{array}$ & $\begin{array}{l}\text { Mar/2011- } \\
\text { Mar/2012 }\end{array}$ & $\begin{array}{c}528.1,528.5 \\
463.3,623.8 \\
447.8,497.8 \\
320.5,337 \\
381 \text { and } 259\end{array}$ & $\begin{array}{c}649.5,580 \\
521.3 \\
520.5,416.3 \\
577.3,326.3 \\
351,389.8 \text { and } \\
282.5\end{array}$ & $\begin{array}{c}41.2,170.3, \\
338.3,495, \\
254,367.3, \\
203.5,216.3 \\
231 \text { and } \\
172.8\end{array}$ & $\begin{array}{l}11.7,7.65 \\
10.2,12, \\
10.25,7.9 \\
7.3,7.71,8.15 \\
\quad \text { and } 5.65\end{array}$ & [26] \\
\hline $\begin{array}{l}\text { Abo Al-Kaseeb, Al-Dear } \\
\text { and Qurna }\end{array}$ & $\begin{array}{l}\text { Dec/2012- } \\
\text { Nov/2013 }\end{array}$ & $\begin{array}{c}705.53, \\
904.70 \text { and } \\
648.43\end{array}$ & $\begin{array}{c}600.3,668.4 \text { and } \\
613.8\end{array}$ & $\begin{array}{l}367.9,423.5 \\
\text { and } 371.5\end{array}$ & $\begin{array}{c}8.13,9.92 \text { and } \\
7.14\end{array}$ & [29] \\
\hline Qurna, Basrah, Maqual, & Jan/2013- & $255,300,575$ & $279.5,409$, & - & - & {$[30]$} \\
\hline
\end{tabular}




\begin{tabular}{|c|c|c|c|c|c|c|}
\hline $\begin{array}{c}\text { Abo Al-Khasib, Sayba and } \\
\text { Al-Fao }\end{array}$ & Apr/2013 & $\begin{array}{c}850,500 \text { and } \\
1100\end{array}$ & $\begin{array}{c}1303,1629, \\
1126 \text { and } 4178\end{array}$ & & & \\
\hline $\begin{array}{c}\text { Five sampling locations } \\
\text { within the Shatt Al Arab } \\
\text { River }\end{array}$ & $\begin{array}{c}\text { winter 2014 } \\
\text { summer 2014 }\end{array}$ & $\begin{array}{c}455.0 \\
562.0\end{array}$ & $\begin{array}{c}732.5 \\
4638\end{array}$ & $\begin{array}{c}654.5 \\
3742\end{array}$ & $\begin{array}{r}11.5 \\
81.9\end{array}$ & {$[31]$} \\
\hline $\begin{array}{c}\text { ALQurna, Paper factory, Al- } \\
\begin{array}{c}\text { Sindebad, Al- Ashare, AL- } \\
\text { Sebah and Al- Fao }\end{array}\end{array}$ & 2015 & $\begin{array}{c}398.11,415.2, \\
438.11,312, \\
295 \text { and } 146\end{array}$ & $\begin{array}{c}435,470,1040, \\
950,2060 \text { and } \\
13350\end{array}$ & - & - & {$[32]$} \\
\hline $\begin{array}{c}\text { St-1, St-2, St-3, St-4, St-5 } \\
\text { and St-6 }\end{array}$ & $\begin{array}{c}\text { Aug., 2016 and } \\
\text { Jan., 2017. }\end{array}$ & $\begin{array}{c}432,412,253, \\
169,163 \text { and } \\
156\end{array}$ & $\begin{array}{c}331,340,519, \\
524,232 \text { and } \\
534\end{array}$ & $\begin{array}{c}375,260, \\
346,323, \\
341 \text { and } 432\end{array}$ & $\begin{array}{c}42.7,71,42, \\
432 \text { and } 121\end{array}$ & {$[34]$} \\
\hline $\begin{array}{c}\text { Shatt Al-Arab River in } \\
\text { Basrah }\end{array}$ & $2016-2017$ & 686.2 & 876.7 & 581.8 & 12.3 & {$[35]$} \\
\hline $\begin{array}{c}\text { The Canal of Shatt Al- } \\
\text { Basrah }\end{array}$ & 2017 & 1888 & 6707 & 6172 & 218 & {$[36]$} \\
\hline
\end{tabular}

7. Chloride $\left(\mathrm{Cl}^{-}\right)$, Sodium $\left(\mathrm{Na}^{+}\right)$and Potassium $\left(\mathrm{K}^{+}\right)$ions

The concentration of $\mathrm{Cl}$ in wastewater is higher than in raw water due to the fact that $\mathrm{NaCl}$ is a diet main article and passes no change in the digestive system. In the coastal area, $\mathrm{Cl}$ exists in large concentrations because of the leakage of saltwater in the system of sewerage. A Cl increased level could harm growing plants, structures as well as metallic pipes [44].

$\mathrm{Na}$ salts are generally soluble highly in water and are drained to surface water and groundwater from the terrestrial environment, majority supplies of water include less than 20 $\mathrm{mg} / \mathrm{l}$, but in several states, it may increase 250 $\mathrm{mg} / \mathrm{l}$. The Na concentration of taste threshold in water relays on the temperature of the solution and associated anions, $\mathrm{Na}$ might influence drinking water taste at levels more than 200 $\mathrm{mg} / \mathrm{l}$ at room temperature [15].

Potassium is an important nutrient which plays a central role in plant growth. Several potassium compounds, mainly potassium nitrate, are used as plants fertilizers added to agricultural soils. Other potassium compounds are used in fluid soap production. The studies that reported the $\mathrm{Cl}^{-}, \mathrm{Na}^{+}$and $\mathrm{K}^{+}$in the River Southern of Iraq are tabulated in Table 4.

\section{Conclusions}

We can conclude from all of the above, the water bodies in Iraq face constantly to many sources of pollution, some of them, natural sources, such as the nature and type of land which the rivers passing through, or low precipitations which cause decrease in flow, and the others, due to human activities, such as untreated waste water, return irrigation flow, industry waste water or illegal practices. There is no easy way, or non-costly, or do not need to big efforts to prevent pollution, otherwise doesn't become the problem of the times. But there are some solutions, proposals and actions that lead to prevent or reduce the concentration of pollutants or mitigate their damages, like:

1- Improvements and enlarged wastewater treatment system on Shatt Al-Arab River and other agricultural, industrial activities, and diversion of untreated discharging effluents from the Shatt Al-Arab River.

2- Establishment of appropriate sanitary facilities on Shatt Al-Arab River domestic sewage.

3- Urgent need for improvements of the river water quality managements to meet the national and world standards.

4- It is of prime importance for establishment of more strict water quality index for Iraqi rivers and lakes. 
5-Closing the factories which do not have waste water processing units, or having processing units, but it is not efficient.

6- Make strict laws to prevent factories using fuel, which cause pollution.

7- Increasing the amount of freshwater discharge to the Shatt Al-Arab River from Tigris and the Euphrates.

8- Constricted a baseline data concerned with the water and sediments qualities of Shatt AlArab River.

\section{Acknowledgments}

The author acknowledges the faculty members of the postgraduate studies of the Department of Environmental Engineering at the College of Engineering, Al-Mustansiriya University (www.uomustansiriyah.edu.iq), especially the professors supervising the master's thesis of the author, Dr. Abdul-Saheb Tawfiq Al-Madhhaji and Dr. Dawood Issa Sajit, for their valuable assistance used in this research.

\section{Conflict of interest}

That the publication of this article causes no conflict of interest.

$\begin{array}{ll}\text { Abbreviations } \\ \text { WT } & \text { Water Temperature } \\ \text { TDS } & \text { Total Dissolved Solids } \\ \text { Sal. } & \text { Salinity } \\ \text { EC } & \text { Electrical Conductivity } \\ \text { TH } & \text { Total Hardness } \\ \mathrm{Ca}^{+2} & \text { Calcium ions } \\ \mathrm{Mg}^{+2} & \text { Magnesium ions } \\ \text { Turb. } & \text { Turbidity } \\ \text { TSS } & \text { Total Suspended Solids } \\ \mathrm{SO}_{4}^{-2} & \text { Sulfate ions } \\ \mathrm{Cl}^{-} & \text {Chloride ions } \\ \mathrm{Na}^{+} & \text {Sodium ions } \\ \mathrm{K}^{+} & \text {Potassium ions }\end{array}$

\section{References}

1. Singh, K. P., Malik, A., Mohan, D., \& Sinha, S. (2004). Multivariate statistical techniques for the evaluation of spatial and temporal variations in water quality of Gomti River (India) — a case study. Water Res., 38, 39803992.

2. Vega, M., Pardo, R., Barrado, E., \& Debán, L. (1998). Assessment of seasonal and polluting effects on the quality of river water by exploratory data analysis. Water Res., 32, 3581-3592.

3. Szymanowska, A., Samecka-Cymerman, A., \& Kempers, A. J. (1999). Heavy metals in three lakes in West Poland. Ecotox Environ Safe., 43, 21-29.

4. Issa, Y. M., Elewa, A. A., Rizk, M. S., \& Hassouna, A. F. A. (1996). Distribution of some heavy metals in Qaroun lake and river Nile, Egypt, Menofiya. J. Agric. Res., 21, 733-746.

5. Poonam, T., Tanushree, B., \& Sukalyan, C., (2013). Water quality indices-important tools for water quality assessment: a review. Int. J. Adv. Chem., 1, 15-28.

6. Niemi, G. J., DeVore, P., Detenbeck, N., Taylor, D., Lima, A., Pastor, J., \& Naiman, R. J. (1990). Overview of case studies on recovery of aquatic systems from disturbance. J. Environ. Manage., 14, 571587.

7. Yuaqub, R. R., \& Salman, H. H. (1992). Some aspects of selected meteorological 
elements in the marshes of Lower Mesopotamia. N.A. Hussain (Ed.). Ahwar of Iraq: Environmental Approach. Marine Science Centre, Basrah University, 299 pp.

8. Yaqoob, Y. F., \& Seikian, F. (1992). Sediments of lakes and marshes in the southern part of Mesopotamia plain. N.A. Hussain (Ed.) Ahwar of Iraq: Environmental Approach. Marine Science Centre, Basrah University, 299 pp.

9. IUCN (International Union Conservancy of Nature). 2005. A Directory of Wetlands in the Middle East. (http://www.wetlands.org/inventoryand/Midd leEastDir/IRAQ1.htm).

10. Elshemy, M., \& Meon, G. (2011). Climate Change Impacts on Water Quality Indices of the Southern Part of Aswan High Dam Reservoir, Lake Nubia. Fifteenth International Water Technology Conference, IWTC-15 2011, Alexandria, Egypt, 17.

11. Bharti, N., \& Katyal, D. (2011). Water quality indices used for surface water vulnerability assessment. Int. J. Environ. Sci., 2, 154-173.

12. Choudhary, P., Routh, J., \& Chakrapani, G. J. (2010). Organic geochemical record of increased productivity in Lake Naukuchiyatal, Kumaun Himalayas, India. Environ Earth Sci., 60, 837-843.

13. Zan, F., Huo, S., Xi, B., Li, Q., Liao, H., Zhang, J. (2010). Phosphorus distribution in the sediments of a shallow eutrophic lake, Lake Chaohu, China. Environ Earth Sci., 62, 1643-1653.

14. WQC, 1963: Water Quality Criteria, California Water Quality Resources Board, Publication No. 3-A.

15. WHO: World Health Organization. (2011). Guidelines for Drinking-Water Quality. 4th edition. Geneva 27, Switzerland.

16. APHA: American Public Health Association. (2005). Standard methods for the examination of water and wastewater, 21st Edition. Washington, DC. USA.

17. Abawi, S. A., \& Hassan, M. S. (1990). Environmental Engineering water analysis. Dar Al-Hikmma press, Al-Mousil University -Iraq. 296. (In Arabic).

18. Mohammed, I. K., Eassa, A. M., \& Mohammed, L. J. (2013). The study of potential environmental risks of some industrial pollutants factors discharged from Najibia Power Plant upon Shatt AlArab River. J. Basrah. Res., 40, 110-121.

19. AL-Saad, H. T., Alhello, A. A., ALKazaeh, D. K., Al-Hello, M. A., Hassan, W. F., \& Mahdi, S. (2015). Analysis of Water Quality Using Physico-Chemical Parameters in the Shatt AL-Arab Estuary, Iraq. Int. J. Mar. Sci., 5, 1-9.

20. Eassa, A. M. (2012). The use of diatom indices for the assessment of Shatt ALArab river water quality. J. Basrah. Res., 38, 114-124. 
21. Aziz, N. M., \& Sabbar, A. A. (2013). Physiochemical Properties of Basrah oil refinery discharges and its potential effects on Shatt Al-Basrah Canal. Marsh Bulletin, 8, 39-57.

22. Hameed, H. A., Ali, M. H., Aljorany, Y. S., Hassan, W. F., \& Al-Hello, A. A. Z. N. (2013). Assessing changes in seawater intrusion and water quality of the Shatt AlArab River, Iraq. Int. J. Lim., 49, 199 206.

23. Hassan, A. A. (2017). Solubility of surface water for drinking purposes in Basrah city Using water quality index (WQI). Iraqi $j$. Civ. Eng., 12, 86-95.

24. Eassa, A. M., \& Mahmood, A. A. (2012). An Assessment of the treated water quality for some drinking water supplies at Basrah. J. Basrah. Res., 38, 95-105.

25. Aldoghachi, M. A. (2017). Oxygen Measurement as an Indicator of the Pollution of the Shatt Al - Arab River and the North - West of the Arabian Gulf. Academy of Agriculture Journal, 2, 52-55.

26. Al-Badran, F. A. A. (2013). Determination of Water Quality Index and Suitability of Shatt Al Arab River and Treated Water for Some Water Treated Plants in Basrah. Basrah J. Eng. Sci., 13, 50-62.

27. Hassan, W. F. (2013). The nitrogen and phosphate forms in water of Shatt Al-Arab River in Basra/ Iraq. Marsh Bulletin, 8, 182-192.
28. Moyel, M. S., Amteghy, A. H., Hassan, W. F., Mahdi, E. A., \& Khalaf, H. H. (2015). Application and evaluation of water quality pollution indices for heavy metal contamination as a monitoring tool in Shatt al Arab River. estuary. Int. j. multidiscip., 3, 67-75.

29. Al-Khuzaie, D. K. K., Abdul-Nabi, Z. A., Husseinal-Maliky, J., Hassan, W., Kzaal, R. S., \& Abood, M. A. (2015). Evaluation the suitability of Shatt al-Arab River water for drinking and irrigation used according to international classification systems. Int j. multidiscip., 3, 18-28.

30. Gatea, M. H. (2018). Study of Water Quality Changes of Shatt Al-Arab River, South of Iraq. J. Univ. Babylon Eng., 26, 228- 241.

31. Dawood, A. S., Hamdan, Ahmed, N. A., \& Khudier, A. S. (2018). Assessment of Water Quality Index with Analysis of Physico-Chemical Parameters (Case Study: The Shatt Al-Arab River-Iraq). IEEF, 5, 93-106.

32. Mahdi, B. A. (2015). Environmental pollution in Shatt al-Arab estuary. Int. $j$. multidiscip., 3, 32-42.

33. Hamdan. A., Dawood, A., \& Naeem, D. (2018). Assessment study of water quality index (WQI) for Shatt Al-Arab River and its branches, Iraq. MATEC Web of Conferences, 162, 05005. 
34. Al-Aboodi, A. H., Abbas, S. A., \&. Ibrahim, H. T. (2018). Effect of Hartha and Najibia power plants on water quality indices of Shatt Al-Arab River, south of Iraq. Appl. Water Sci., 8, 1-10.

35. Al-Adhab, H., Salman, A., \& Sagban, A. (2019). Using multivariate statistical methods to Evaluate water quality in some of Basrah province locations. Proceeding of ICCEET, 2019, 65-72.

36. Hassan, A. A., Dawood, A. S., \& ALMansori, N. J. (2018). Assessment of Water Quality of Shatt Al-Basrah Canal using Water Pollution Index. Int. J. Eng. Technol., 7, 757-762.

37. Al-Mayah, A. A., \& Al-Asadi, W. M. (2018). The impact of increase Salinity on the Aquatic Plants assemblage in Shatt AlArab river, Iraq. Marsh Bulletin, 13, 74-86.

38. Lind, O.T. (1979). Handbook of common method in limnology, 2nd edition. C.V. mosby Co., ST. Louis.

39. Carlson, M. P., \& Ensley, S. (2007). Water quality and contaminants. Chapter, 85:1045-1059 in Veterinary Toxicology, Edited by Ramesh C. Gupta Copyright ${ }^{\odot}$ 2007, Elsevier Inc.

40. Pradeep, V., Deepika, C., Urvi, G., \& Hitesh, S. (2012). Water Quality Analysis of an Organically Polluted Lake by Investigating Different Physical and
Chemical Parameters. Int. J. Res. Chem. Environ., 2, 105-111.

41. Moyel, M. S., Amteghy, A. H., Naseer, T. K., Mahdi, E. A., Younus, B. M., \& Albadran, M. A. (2013). Comparison of total hardness, calcium and magnesium concentrations in drinking water (RO), and municipal water with WHO and local authorities at Basrah province, Iraq. Marsh Bulletin, 8, 65-75.

42. Simões, F., Moreira, A. B., Bisinot, M. C., Gimenez, S. M., \& Yaba, M. J. (2008). Water quality index as a simple indicator of aquaculture effects on aquatic bodies. Ecological Indicator, 8, 476-484.

43. Abel, P. D. (2002). Water Pollution Biology. 2nd ed. Copyright $\odot$ Taylor \& Francis Ltd.

44. UNEP and WHO (United Nation Environmental Programme and World Health Organization) (1996). Water quality monitoring: A practical guide to the design and implementation of fresh water quality studies monitoring programmers. 